\title{
Effect of potato varieties and nitrogen levels on dry matter accumulation, chlorophyll content, grade wise tuber yield and post harvest nutrient content in plant and soil
}

\author{
A.S. Jatav, S.S. Kushwah*, S.N. Mishra and I.S. Naruka \\ College of Horticulture (Campus of RVSKVV), MANDSAUR (M.P.) INDIA \\ (Email : kushwahhort@gmail.com)
}

\begin{abstract}
A field investigation was carried out at vegetable research field, College of Horticulture, Mandsaur during Rabi season 2010-11. The soil of the experimental field was light alluvial with sandy loam texture and uniform topography. Sixteen treatment combinations of four varieties ( $\mathrm{V}_{1}$-Kufri Jyoti, $\mathrm{V}_{2}$-Kufri Chipsona-2, $\mathrm{V}_{3}$-Kufri Chipsona-1 and $\mathrm{V}_{4}$-Kufri Pushkar) and four nitrogen doses $\left(\mathrm{N}_{1}-100 \mathrm{~kg} / \mathrm{ha}, \mathrm{N}_{2}-125 \mathrm{~kg} / \mathrm{ha}, \mathrm{N}_{3}-150 \mathrm{~kg} / \mathrm{ha}\right.$ and $\left.\mathrm{N}_{4}-175 \mathrm{~kg} / \mathrm{ha}\right)$ were replicated thrice in Factorial Randomized Block Design. The findings of the experiment revealed that among the varieties, Kufri Pushkar recorded maximum leaf area per plant, chlorophyll content in leaves, dry weight of shoot, root and tuber. Maximum 'A' grade tuber yield was found with variety Kufri Jyoti followed by Kufri Pushkar. 'B' grade tuber yield was found maximum in case of variety Kufri Pushkar followed by Kufri Chipsona-1 and Kufri Jyoti. Analysis of plant after harvesting revealed significant influence of varieties on nitrogen, phosphorus and potassium content in plant. Maximum nitrogen and phosphorus content in plant was recorded with variety Kufri Pushkar. Potassium content in plant showed highest values with variety Kufri Jyoti. Analysis of soil after harvesting recorded significant influence of varieties on available NPK in soil. Highest available nitrogen, phosphorus and potassium were recorded with Kufri Chipsona-2. Nitrogen application enhanced the leaf area and chlorophyll content. Dry weight of shoot, root and tuber was recorded significant influence of nitrogen levels at all the stages. Highest dry weight of shoot, root and tuber was found with application of $150 \mathrm{~kg}$ N/ ha. Nitrogen application had significant effect on grade wise tuber yield. There was increase in 'A' grade tuber yield with increasing levels of nitrogen upto $150 \mathrm{~kg} / \mathrm{ha}$. Application of nitrogen showed increase in nitrogen, phosphorus and potassium content upto $150 \mathrm{~kg} / \mathrm{ha}$. It also caused increase in available nitrogen and decrease in available phosphorus and potassium in soil. Combined effect of varieties and nitrogen recorded significant effect on chlorophyll content in leaves at 60 DAP. Highest chlorophyll content was found with $\mathrm{V}_{4} \mathrm{~N}_{3}$. Dry weight of shoot, root and tuber showed significant interaction effect of varieties and nitrogen levels at 90 DAP. Highest fresh weight of tuber and 'A' grade tuber yield was found under $\mathrm{V}_{4} \mathrm{~N}_{3}$. There was significant effect of varieties and nitrogen levels interaction on nitrogen and phosphorus content in plant and available potassium in soil after harvesting.
\end{abstract}

Key Words : Potato, Varieties, Nitrogen, Chlorophyll, Grade wise tuber, Nutrient, Plant, Soil

View Point Article : Jatav, A.S., Kushwah, S.S., Mishra, S.N. and Naruka, I.S. (2018). Effect of potato varieties and nitrogen levels on dry matter accumulation, chlorophyll content, grade wise tuber yield and post harvest nutrient content in plant and soil. Internat. J. agric. Sci., 14 (1) : 46-55, DOI:10.15740/HAS/IJAS/14.1/46-55.

Article History : Received : 16.05.2017; Revised : 05.11.2017; Accepted : 18.11.2017

* Author for correspondence: 